\title{
THE EFFECT OF DIFFERENT OPENING CONFIGURATION IN MULTI-STORY RC BUILDING WITH SHEAR WALL
}

\author{
Priya B. Kale \\ P.G. Student Civil Dept. \\ Saraswati College of Engineering, Kharghar, India
}

\begin{abstract}
Shear walls are effective structural elements used mainly in multi-story buildings to provide resistance against lateral loadings such as earthquake and wind loadings. They have high plane stiffness and strength which can be used to simultaneously resist large horizontal loads while also supporting gravity loads. Hence it is necessary to determine effective and ideal locations of shear walls. Shear wall arrangement must be absolutely accurate, if not, it may cause negative effects instead. A shear wall may contain many openings due to the functional requirements such as doors and windows, which may largely affect the overall seismic response of the structure. In this project, a study has been carried out to determine the effects of combination of shear walls positions and also the optimum structural configuration of multi-storey buildings by providing the shear wall with different openings configuration. This study is carried out on a $\mathbf{G + 3 0}$ story frame shear wall building, with the help of computer application software ETABS, using Response Spectrum method. The comparative results showed that the, time period, top displacement, base shears, story drift and stress distribution around the openings depend on the opening arrangement system.
\end{abstract}

Keywords - Shear Wall, Staggered Openings, Seismic Loads, Finite Element Analysis, Response Spectrum Method

\section{INTRODUCTION}

Shear walls are vertical elements of the horizontal force resisting system. Shear walls are constructed to counter the effects of lateral load acting on a structure. In residential construction, shear walls are straight external walls that typically form a box which provides all of the lateral support for the building. When shear walls are designed and constructed properly, and they will have the strength and stiffness to resist the horizontal forces.

Shear walls are especially important in high-rise buildings subjected to lateral wind and seismic forces. Shear walls are constructed from the level of foundation to the top story. In regular plan building, Symmetrical placement of

\author{
Roshni John \\ Associate Professor Civil Department \\ Saraswati College of Engineering, Kharghar, India
}

shear wall can be preferred. For the sake of architectural purpose, plan of the building may be irregular one. For that plan, location of shear wall should be effective.

Shear walls resist two types of forces: shear forces and uplift forces. Shear forces are generated in stationary buildings by accelerations resulting from ground movement and by external forces like wind and waves. This action creates shear forces throughout the height of the wall between the top and bottom shear wall connections. Shear walls must provide the necessary lateral strength to resist horizontal earthquake forces. When shear walls are strong enough, they will transfer these horizontal forces to the next element in the load path below them. These other components in the load path may be other shear walls, floors, foundation walls, slabs or footings. Shear walls should be located on each level of the structure including the crawl space. To form an effective box structure, equal length shear walls should be placed symmetrically on all four exterior walls of the building. Shear walls should be added to the building interior when the exterior walls cannot provide sufficient strength and stiffness. Shear walls in high rise structures will be perforated with many openings that are essential for windows in external walls or corridors and door openings for internal wall. The location and size of opening depends on the role of opening. However the size of the opening may affect the overall seismic response of the system. The openings may arrange staggered or vertically ordered manner. In this present work attempt is made to study and investigate the RC framed structures by introducing staggered and regular opened shear wall on different positions. For this study $\mathrm{G}+30$ buildings are considered and finding which opened shear wall is more advantageous and also their positions, by using finite element software ETAB v 15 at seismic zone III.

\section{MODEL DESCRIPTION}

For this study, a G+30 story, $7 \times 7$ bays frame-shear wall building with $5 \mathrm{~m}$ span in both directions and floor height of $2.9 \mathrm{~m}$ was modeled without opening, with vertical opening and with staggered opening in shear wall, using the finite element software ETABS. Typical floor plan with dimensions $35 \mathrm{~m} \times$ 


\section{International Journal of Engineering Applied Sciences and Technology, 2019 \\ Vol. 4, Issue 5, ISSN No. 2455-2143, Pages 366-370 \\ Published Online September 2019 in IJEAST (http://www.ijeast.com)}

$35 \mathrm{~m}$ was used for all three models. Shear wall is provided at periphery and middle core.

The model was meshed in order to obtain results with higher accuracy. The earthquake load and load combinations were applied as per IS 1893 - 2016 and the seismic analysis was done by response spectrum method. The shear wall was designed using limit state method and was detailed as per IS $456-2000$ and IS 13920 - 1993 respectively.

Table1.Building Configuration

\begin{tabular}{|l|l|}
\hline No of stories & G+30+Terrace \\
\hline Type of Structure & SMRF having shear walls \\
\hline Size of Column & $700 \times 700 \mathrm{~mm}$ \\
\hline Size of Beam & $230 \times 500 \mathrm{~mm}$ \\
\hline Depth Of Slab & $150 \mathrm{~mm}$ \\
\hline Type of Slab & Shell type \\
\hline $\begin{array}{l}\text { Thickness of Shear } \\
\text { Wall }\end{array}$ & $230 \mathrm{~mm}$ \\
\hline Opening Size & $2.14 \times 0.96 \mathrm{~m}$ \\
\hline Height of each storey & $2.9 \mathrm{~m}$ \\
\hline Support condition & Fixed at base \\
\hline Grade of Concrete & $\begin{array}{l}\text { M50 for Shear wall \& column } \\
\mathrm{M} 35 \text { for beams and slabs }\end{array}$ \\
\hline Grade of Steel & Fe 500 \\
\hline Density of Concrete & $25 \mathrm{KN} / \mathrm{m}^{3}$ \\
\hline Density of wall & $9 \mathrm{KN} / \mathrm{m}^{3}$ \\
\hline
\end{tabular}

Table2. Loads

\begin{tabular}{|l|l|l|}
\hline Dead Load & As per structure \\
\hline \multirow{2}{*}{ Live Load } & On Floor & $2 \mathrm{KN} / \mathrm{m}^{2}$ \\
\cline { 2 - 3 } & On Roof & $1.5 \mathrm{KN} / \mathrm{m}^{2}$ \\
\hline Floor Finish & $1.5 \mathrm{KN} / \mathrm{m}^{2}$ \\
\hline
\end{tabular}

Table3. Seismic Data

\begin{tabular}{|l|l|}
\hline seismic zone & III \\
\hline zone factor & 0.16 \\
\hline Response reduction factor, R & 5 \\
\hline Importance factor & 1.2 \\
\hline soil type & I, Hard \\
\hline Damping & $5 \%$ \\
\hline
\end{tabular}

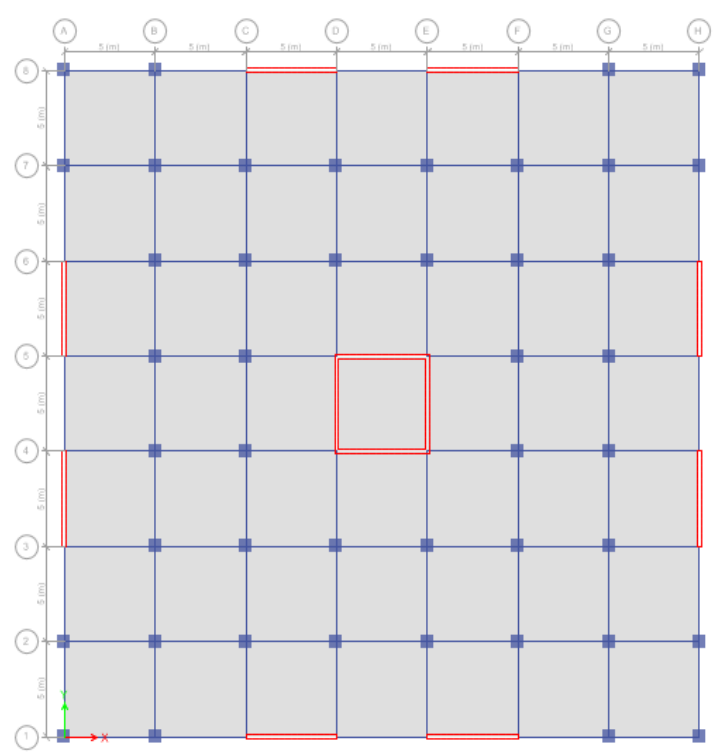

Fig. 1 Plan view

For this project, three models were made. Their descriptions are as follows:

Case [1] Building with Shear Walls without Opening (Fig.2)

Case [2] Building with Shear Walls with Normal Opening (Fig.3)

Case [3] Building with Shear Walls with Staggered Opening (Fig.4)

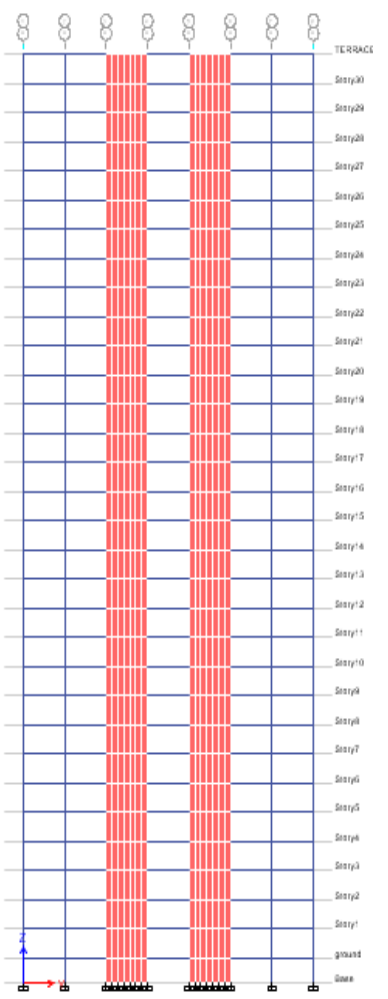

Fig. 2 Shear Walls without Opening 
International Journal of Engineering Applied Sciences and Technology, 2019 Vol. 4, Issue 5, ISSN No. 2455-2143, Pages 366-370

Published Online September 2019 in IJEAST (http://www.ijeast.com)

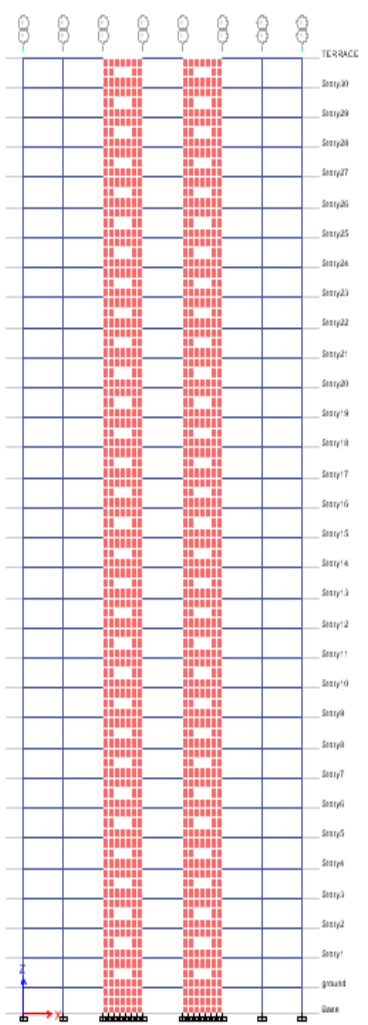

Fig. 3 Shear Walls with Normal Opening

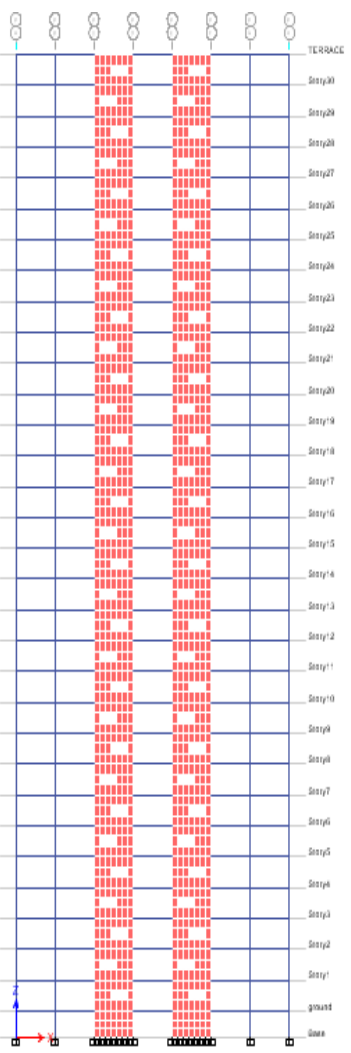

Fig. 4 Shear Walls with Staggered Opening

\section{RESULTS AND DISCUSSION}

The Result describes Time period, Base shear, Story drift, Story displacement and Stress distribution.

Table4. Result Table

\begin{tabular}{|l|l|l|l|l|}
\hline & $\begin{array}{l}\text { Time } \\
\text { period } \\
(\mathrm{sec})\end{array}$ & $\begin{array}{l}\text { Story } \\
\text { Shear } \\
(\mathrm{kN})\end{array}$ & $\begin{array}{l}\text { Story } \\
\text { Drift } \\
(\mathrm{mm})\end{array}$ & $\begin{array}{l}\text { Story } \\
\text { Displacement } \\
(\mathrm{mm})\end{array}$ \\
\hline $\begin{array}{l}\text { Shear } \\
\text { wall } \\
\text { without } \\
\text { Openings }\end{array}$ & 3.967 & 2312.053 & 0.000388 & 26.441 \\
\hline $\begin{array}{l}\text { Shear } \\
\text { wall with } \\
\text { Vertical } \\
\text { Openings }\end{array}$ & 4.113 & 2085.805 & 0.000415 & 27.879 \\
\hline $\begin{array}{l}\text { Shear } \\
\text { wall with } \\
\text { Staggered } \\
\text { Openings }\end{array}$ & 4.156 & 1972.157 & 0.000431 & 28.324 \\
\hline
\end{tabular}

A. Time Period- The time period obtained from the analysis for all three models is shown in Fig. 5. It can be seen that the staggered openings exhibited a higher value of time period when compared to vertical openings, which indicates that the shear wall with staggered openings can perform better during seismic action than the vertical openings.

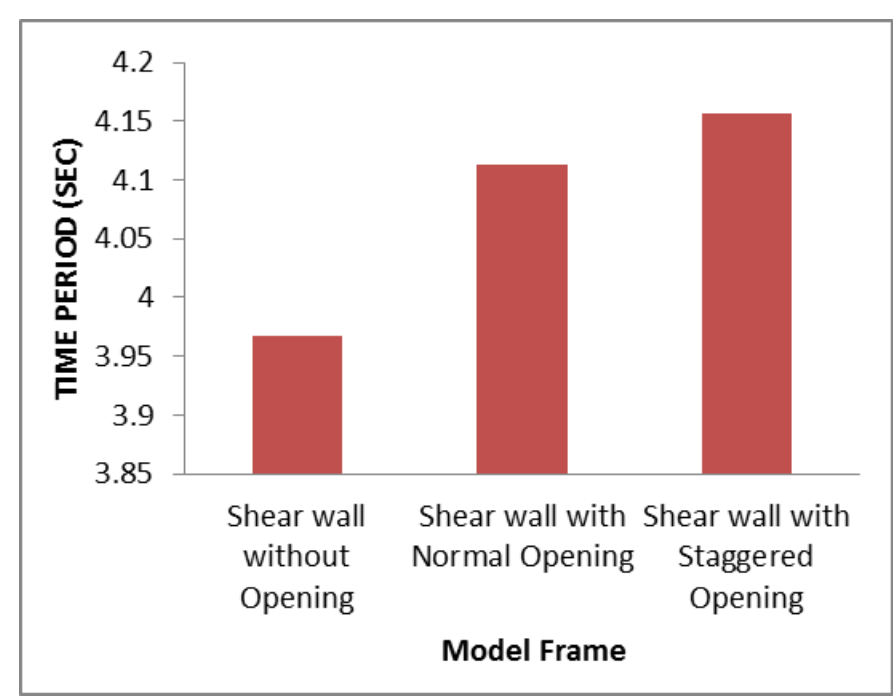

Fig. 5 Time period 


\section{International Journal of Engineering Applied Sciences and Technology, 2019 \\ Vol. 4, Issue 5, ISSN No. 2455-2143, Pages 366-370 \\ Published Online September 2019 in IJEAST (http://www.ijeast.com)}

B. Story Shear-It is an estimate of the maximum expected lateral force that will occur due to seismic ground motion at the base of a structure. The base shear is found to be much lesser for shear wall with staggered openings when compared to shear wall with vertical openings, in both the directions. As the base shear is reduced, the shear wall with staggered openings will be less susceptible to damage.

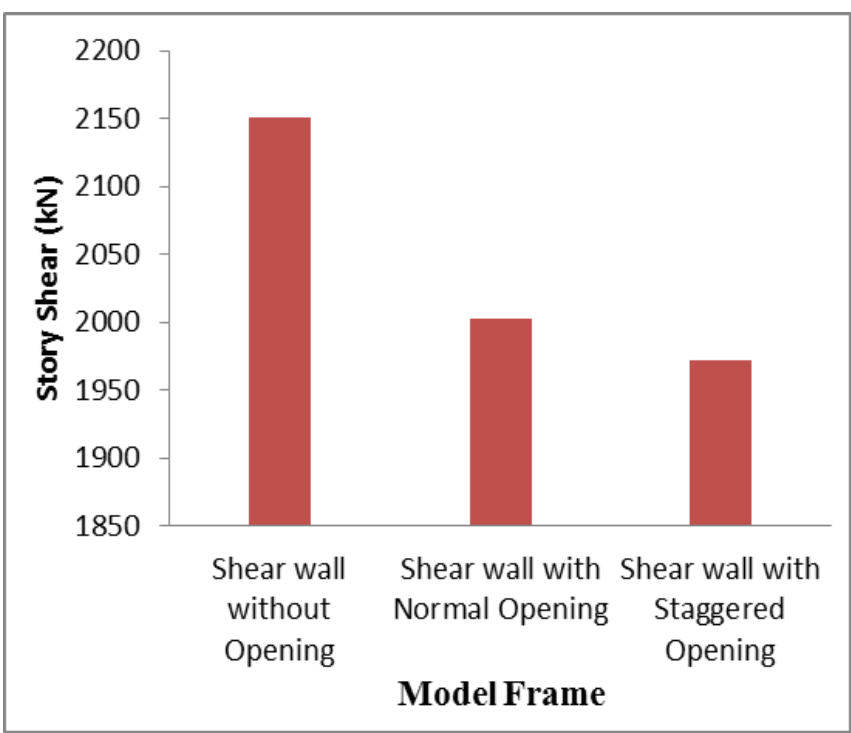

Fig. 6 Story Shear

C. Story Drift- Story drift is defined as the displacement of one level relative to the other level above or below. According to IS: 1893 (Part I) - 2016, the story drift for buildings is limited to 0.004 times the story height, which was not exceeded in our analytical study for all three models. In case of story drift, the shear wall with vertical as well as staggered arrangement of openings shows no significant difference.

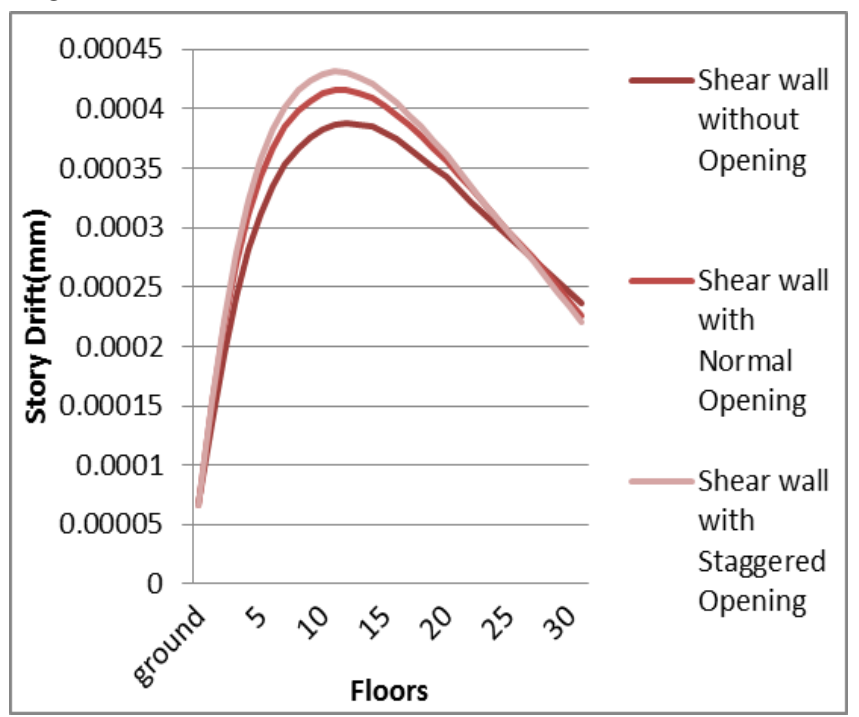

\section{Fig. 7 Story Drift}

D. Story Displacement- The displacement refers to the distance that points on the ground are moved from their initial locations by the seismic waves. The shear wall with staggered openings experiences a higher displacement than vertical openings due to the fact that, in the case of buildings with a long natural period, the buildings will experience lower accelerations but larger displacements.

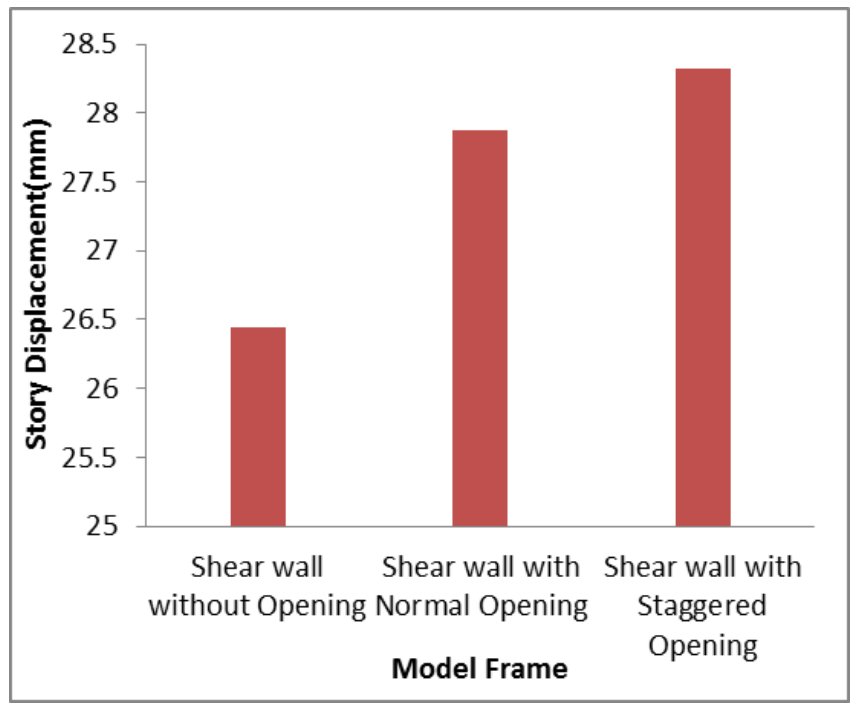

Fig. 8 Story Displacement

\section{CONCLUSION}

After investigating all the models in this paper we conclude that:

1. Presence of opening, decreases strength and stiffness.

2. The displacement and drift in staggered openings agreed quite well than that of vertical openings.

3. The base shear is found to be much lesser for shear wall with staggered openings compared to regular opening.

4. Time period is high for staggered opening. So, it is less susceptible to damage.

5. Thus the staggered openings in shear wall shows highly advantageous and they were provide better lateral resistance strength to the structure compared to regular opened shear wall.

\section{AKNOWLEDGEMENT}

It's a great pleasure and moment of immense satisfaction for me to express my profound gratitude to my guide Prof. Roshni John, Head of Department whose constant encouragement enabled me to work enthusiastically. Her perpetual motivation, patience and excellent expertise in discussion during progress 


\section{International Journal of Engineering Applied Sciences and Technology, 2019 Vol. 4, Issue 5, ISSN No. 2455-2143, Pages 366-370 \\ Published Online September 2019 in IJEAST (http://www.ijeast.com)}

of the project work have benefited me to an extent, which is beyond expression.

\section{REFERENCE}

[1] Abhija Mohan, Aarathi S.(2017) "Comparison of $R C$ Shear Wall with Openings in Regular and Irregular Building” IJERT Vol. 6 Issue 06.

[2] Aarthi Harini T and G.Senthil Kumar(2015) "Behavior of R.C. Shear Wall with Staggered Openings under Seismic Loads" International Journal For Research In Emerging Science And Technology, Volume-2, Issue-3.

[3] A.Titiksh, G. Bhatt(2017)“ optimum Positioning Of Shear Walls For Minimizing The Effects Of Lateral Forces In Multistorey-buildings" Archives of civil engineering Vol. LXIII Issue1

[4] Agarwal P., Shrikhande M (2011) "Earthquake resistant design of structure" Ninth edition..

[5] M.A.Husain and O.I.Mahmood (2017) "Comparative Study for Different Types of Shear Walls in Buildings Subjected to Earthquake Loading “ Al-Nahrain Journal for Engineering Sciences (NJES) Vol.20 No.2, pp. 358367

[6] M.S.Kodappana, Priyanka Dilip(2017)“Study on Dynamic Behaviour of Shear walls with Staggered Openings in Irregular R.C. Framed Structures'”IJSRSET, Volume 3 Issue 2.

[7] Mosoarca Marius(2013) "Seismic behaviour of reinforced concrete shear walls with regular and staggered openings after the strong earthquakes between 2009 and 2011" Article in press engineering failure analysis.

[8] S.R.Chowdhury , M.A. Rahman, M.J.Islam , A.K.Das(2012) "Effects of Openings in Shear Wall on Seismic Response of Structures “ International Journal of Computer Applications (0975 - 8887) Volume 59- No.1

[9] Krishna G S, Chaithra S (2017) "Comparative Study of Frame Shearwall Building With Different Opening Configurations" International Journal of Advance Engineering and Research Development Volume 4, Issue 5.

[10] Swetha K. S., Akhil P.A. (2017) "Effect of Openings in Shear Wall" International Research Journal of Engineering and Technology (IRJET) Volume: 04 Issue: 05.

[11] Taranath B.S,(1988) "Structural analysis and design of tall building", McGraw-Hill.
[12]IS 1893(Part 1):2016 6th edition criteria for earthquake resistant design of structure; Bureau of Indian standards New Delhi, India. 